\title{
Effects of Temperature and Catalyst Mass on the Mechanical Properties of Urea Formaldehyde Resinated Cotton Fabrics
}

\author{
Ezeribe A.I. ${ }^{1}$, K.A.Bello ${ }^{2}$, Adamu H. M. ${ }^{3}$ boryo D. E. A. ${ }^{1}$ Omar, Pan $^{4}$ \\ 1. Department of SLT., Federal Polytechnic, Bauchi. \\ 2. Department of Textile Technology A.B.U Zaria \\ 3. Department of Chemistry, A.T.B.U. Bauchi. \\ Department of General Studies, Federal Polytechnic, Bauchi
}

\begin{abstract}
The dipole forces which facilitate reaction are temperature dependent. Allowing fabrics to over cure degrades the cotton due to excessive heat and distort the attractive force between polar groups of resin - cotton network. Effects of temperature and catalyst mass on the breaking load (BL) and dry crease recovery angle (DRCA) of mono urea formaldehyde resin (MUFR) through Tetra urea formaldehyde resins (TUFR) resinated fabrics were carried out on chemically treated cotton fabrics, and was cured at $40^{\circ} \mathrm{C}$ to $170^{\circ} \mathrm{C}$. The result obtained reveal the combined effects of temperature and catalyst mass on the monomethylol urea resinated fabric samples cured at $120^{\circ} \mathrm{C}$ (MUFR 120) gave a BL of $7.84 \mathrm{kgf}$ at $120^{\circ} \mathrm{C}$ and $7.40 \mathrm{kgf}$ at $100^{\circ} \mathrm{C}$ along the warp direction, between $0.75 \mathrm{~g}$ to $1.0 \mathrm{~g}$ of catalyst. Dimethylol urea resinated cotton fabrics samples cured at $150^{\circ} \mathrm{C}$ (DURF150) gave a BL of $10.01 \mathrm{kgf}$, this is followed by DSUFR 120 sample cured at $120^{\circ} \mathrm{C}$ which gave a BL of $8.21 \mathrm{kgf}$. In fig. 27 , trimethylol urea resinated samples cured at $80^{\circ} \mathrm{C}$ ( TRUFR $80^{\circ} \mathrm{C}$ ) gave the highest BL of $11.32 \mathrm{kgf}$ between $0.75 \mathrm{~g}$ to $1.0 \mathrm{~g}$ of catalyst. Further increase in curing temperature and mass of catalyst was counterproductive and reduced the tensile strength of samples by $8.0 \% ; 48 \%$ and $38 \%$ in DUFR, TRUFR and TUFR samples respectively in the warp axis. The trend replicated itself in weft axis, which gave the maximum $\mathrm{BL}$ of $10.01 \mathrm{kgf}$ at $150^{\circ} \mathrm{C}$ but failed around $9.26 \mathrm{kgf}$ at $170^{\circ} \mathrm{C}$ representing a loss in tensile strength of $8 \%$ in the weft axis. The DCRA increased with temperature and catalyst mass but reduced as catalyst mass exceed $1.0 \mathrm{~g}$. Resins prepared with $0.75 \mathrm{~g}$ to $1.00 \mathrm{~g}$ of catalyst and it resinated fabrics cured between $150^{\circ} \mathrm{C}$ to $155^{\circ} \mathrm{C}$ would improve the DCRA and BL of cotton fabrics.
\end{abstract}

Keywords: - Breaking Load (BL),Dry Crease Recovery Angle(DCRA) Stensile strength, Combined Effect of Catalyst Mass,

\section{INTRODUCTION}

Vale and Taylor(1964) reported that monomeric or dimeric methylol urea react at elevated temperature in the presence of alkaline catalyst to yield only short chain polymers. The polymers are solubilized by attached methylol group. The methylol group is protonated under acid conditions giving rise to a reactive intermediate which is resonance stabilized carbonium imonium (Othman, 1978). The present of catalyst in reactions, increase number of collisions between active centers and monomers. These lead to production of resins, with higher molecular masses and viscosity. Catalyst provides an additional path or mechanism for the reaction. This is further explained in terms of pole vaulting analogy (Robert et al; 1975). When catalyst is added, there is a new path, hence a different activation energy barrier, this new reaction path corresponds to a new reaction mechanism that permits the reaction to occur via different activated complex. Thus more particles can get over the new lower energy barrier and reaction rate is increased (Robert et al; 1975).. The nature of the product is greatly dependent on the reactants (Fred, 1984). Additional liberation of formaldehyde by thermal or hydrolytic cleavage are reduced by the type and amount of catalyst used (Peterson, 1997). Polymer sample exhibit glasslike behavior at low temperature and high frequency with young modulus of $10^{9}-10^{10} \mathrm{~N} / \mathrm{m}^{2}$ and will break or flow at strains greater than $5 \%$. At high temperature, the same polymer may be rubber - like with modulus of $10^{6}$ to $10^{7} \mathrm{~N} / \mathrm{M}^{2}$ withstanding large extensions of about (100\%) with permanent deformation (Jame et al; 1975). Still at higher temperature, permanent deformation occurs under load and behaves like a highly viscous liquid.

The reaction of urea by Holzer(1884) and the treatment of regenerated cellulose to improve the strength (Eschewer, 1979),gave birth to successful preparation and application of resins to textile fabrics. When resinated samples are cross-linked, the dimensional stability is improved, the creep propensity is lowered, resilience increases and resin structure becomes less prone to heat distortion due to increase in rigidity of molecular chain, strong intermolecular forces and subsequently increase in glass transition temperature $\left(\mathrm{T}_{\mathrm{g}}\right)$. There is also great restriction in chain slippage due to the dimensional network structure (Billimeyer, 1984). Fabric finishing consists of mechanical, chemical and thermal processes, applied to fabrics to produce or impact specific performance level. Resination or fiber-resin complex is one of such fabric finish. Apparel made from cellulose, 
regenerated cellulose/ blend of these with synthetic fibers have the tendency to wrinkle badly after washing and timble drying or wearing.

Resination improves fabric wrinkle resistance durable press performance (Siviwan, 2002).

The relative amounts of crystalline and amorphous portion of cellulose influence the properties of cellulose fiber. The crystallinity of cotton is between 85 and 95 percent, giving cotton fiber moderate strength and abrasion resistance. Temperature and time of cure are important variables control as to obtain good crosslinking and low formaldehyde release in treated cotton fabric. Fabric treated with urea formaldehyde resins are easy to cure and should be cured as soon as the fabric is dried, to avoid reactants self cross-link. Curing temperature of $130^{\circ} \mathrm{C}$ to $150^{\circ} \mathrm{C}$ is strongly recommended for methylol urea resins (Cook et al; 1982b).

\section{MATERIALS AND METHODS}

\section{Preparation of urea formaldehyde resins}

Polymerization reaction of urea formaldehyde resins was carried out in two stages (Trotman, 1975), the low molecular mass, fusible and soluble resins was made by the reaction of I mole of urea with 1,2,3,4 moles of formaldehyde to produce mono, di, tri, tetra, methylol urea respectively. 1mole urea was dissolved in $30 \mathrm{~cm}^{3}$ of formaldehyde to produce mono-, di, tri and tetra methylol urea respectively in $0.5 \mathrm{~g}, 0.75 \mathrm{~g}, 1.0 \mathrm{~g}, 1.25 \mathrm{~g}$ and $1.50 \mathrm{~g}$ of potassium dihydrogen phosphate $\left(\mathrm{KH}_{2} \mathrm{PO}_{4}\right)$. Few drops of sodium carbonate solution were added to maintain the $\mathrm{pH}$ at about 7-8. The reaction was carried out at $40^{\circ} \mathrm{C}$ for $8-12$ hours. The resulting syrup was filtered and washed with ethanol to remove any unreacted formaldehyde. The mono methylol urea resin was dried in the oven for 2 hours at $40^{\circ} \mathrm{C}$.

\section{Resin Application}

The mercerized samples $(5 \times 1 \mathrm{~cm})$ were impregnated with $30 \mathrm{mls}$ each of $0.5 \mathrm{~g}, 0.75 \mathrm{~g}, 1.0 \mathrm{~g}, 1.25 \mathrm{~g}$ and $1.5 \mathrm{~g}$ $\mathrm{KH}_{2} \mathrm{PO}_{4}$ catalyzed mono through tetra methylol urea for $30 \mathrm{~min}$. followed by occasional padding on a smooth surface to achieve even treatment and also to remove excess resins. The curing reaction, leading to the crosslinking of substrate molecule with resin was carried out by exhaustion method at $40^{\circ} \mathrm{C} 60^{\circ} \mathrm{C}, 80^{\circ} \mathrm{C}, 100^{\circ} \mathrm{C}$, $120^{\circ} \mathrm{C}$ and $170^{\circ} \mathrm{C}$ in the oven for 45 minutes.

\section{MEASUREMENT OF MECHANICAL PROPERTIES}

\section{Crease recovery measurement}

The crease recovery property of treated fabric was carried out in accordance with British Standard specification (1974), the resinated fabric specimen measuring $1.0 \mathrm{~cm}$ by $5.0 \mathrm{~cm}$ was creased by application of a load of $2 \mathrm{~kg}$ in a Shirly Crease Recovery Tester for $5 \mathrm{~min}$. The load was removed and the specimen was allowed to recover for $5 \mathrm{~min}$. The Shirly Crease Recovery Tester was calibrated by adjusting the knob to face the $0^{\circ}$ mark, and the specimen was then transferred to the Crease Recovery Tester to measure the crease recovery angle in the warp and weft directions.

\section{Breaking load measurement}

The sample measuring $1.0 \mathrm{~cm}$ x $5.0 \mathrm{~cm}$ was mounted on the Instron 1026 Tensile Tester. The gauge length of instron was adjusted to accommodate the sample. The instrument was operated at a speed of $10 \mathrm{~mm} / \mathrm{min}$ and the load extension values of the instrument were recorded for various mass of mono through Tetra, catalysed methylol urea resins respectively. The breaking load values of the instrument were recorded at various concentration of mono through tetra catalyzed methylol urea resins, cured at $40^{\circ} \mathrm{C}$ through $170^{\circ} \mathrm{C}$ respectively.

\section{Effect of temperature on resinated cotton fabric}

Resinated samples were dried and cured in Gallen Kamp electric oven at $40^{\circ} \mathrm{C}, 60^{\circ} \mathrm{C}, 80^{\circ} \mathrm{C}, 100^{\circ} \mathrm{C}$ $120^{\circ} \mathrm{C}, 150^{\circ} \mathrm{C}$ and $170^{\circ} \mathrm{C}$ for $30 \mathrm{~min}$. These samples of dimension $5.0 \mathrm{~cm}$ x $1.0 \mathrm{~cm}$ were separately mounted on the Instron 1026 Tensile Tester at constant gauge length of $5 \mathrm{~cm}$ and speed of $010 \mathrm{~mm} / \mathrm{min}$. the breaking load values of the instrument were recorded at various mass of mono through tetra catalyzed methylol urea resins respectively.

\section{RESULTS}

Figs 25, 26, 27, and 28 show the effects of temperature and catalyst mass on breaking load of mono methylol, tri methylol, tetra methylol resinated cotton fabrics (warp) respectively at $\mathrm{pH}$ of 8.0. Also, figures 29, 30,31 and 32 reveal same on the weft direction. Figs 14 and 17 depict the effect of catalyst mass on the dry crease recovery angle ( DCRA) of dimethylol urea resinated cotton fabrics in warp and weft axis. 


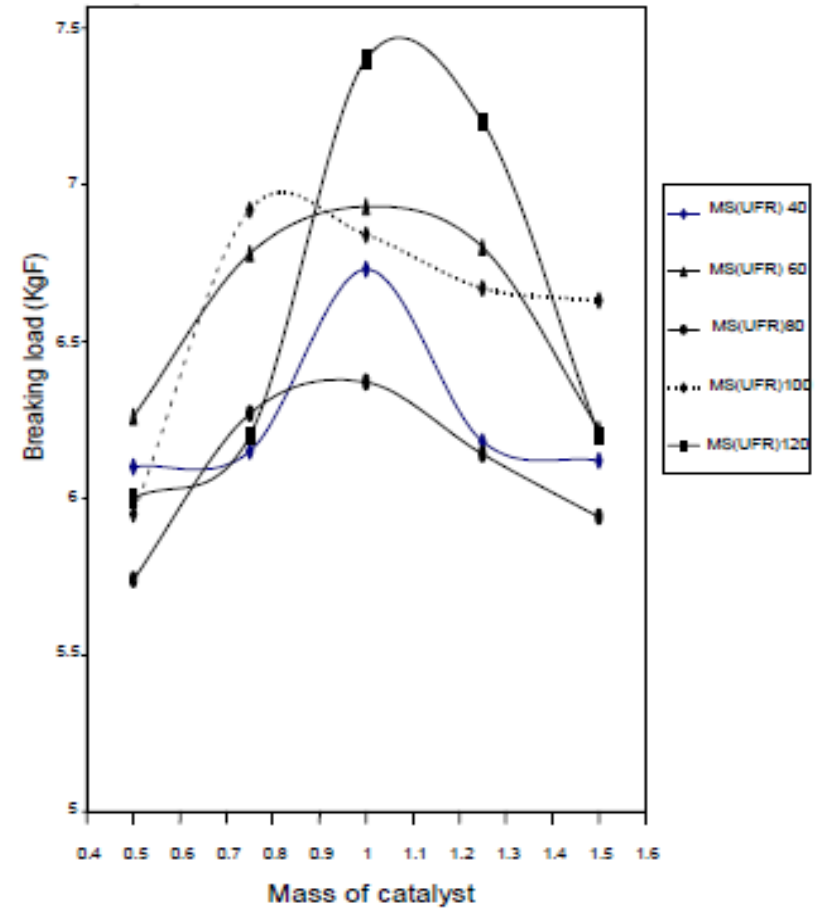

Fig. 25: Effect of temperature on breaking load of mono substituted resinated cotton fabric at $\mathrm{pH}$ of 8.0

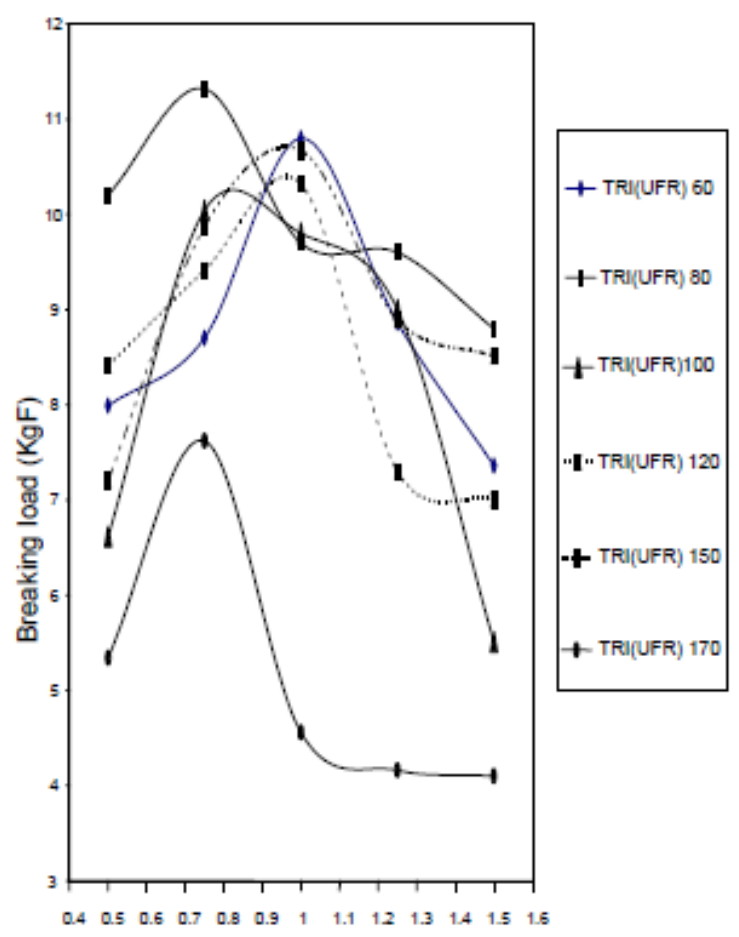

Mass of catalyst

Fig. 27: Effect of temperature on breaking load of trisubstituted resinated cotton fabric at $\mathrm{pH}$ of 8 (WARP)

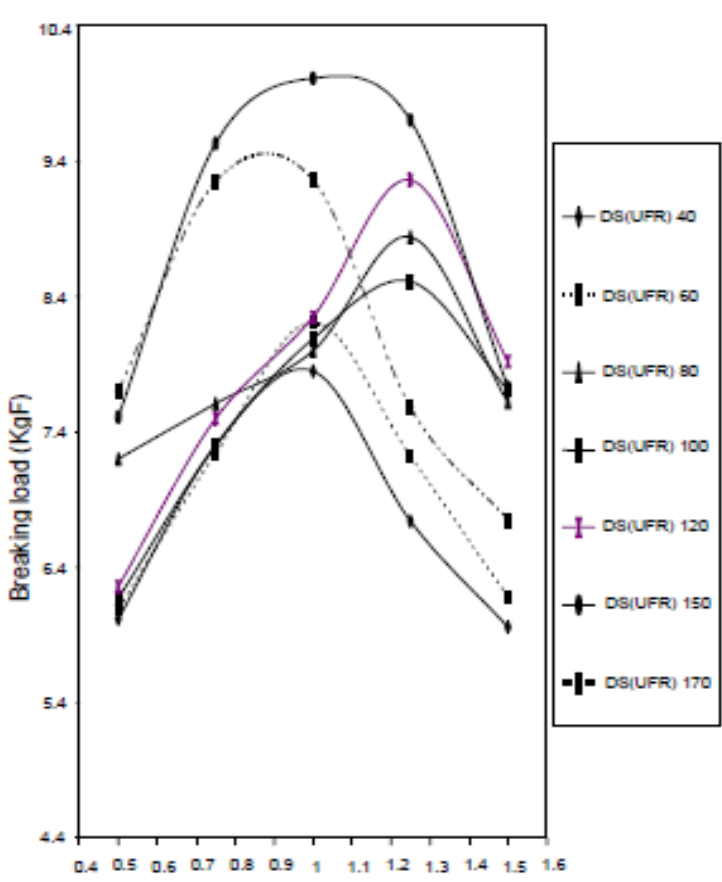

Mass of catalyst

Fig. 26: Effect of temperature on breaking load of disubstituted resinated cotton fabric at $\mathrm{pH}$ of 8 (WARP)

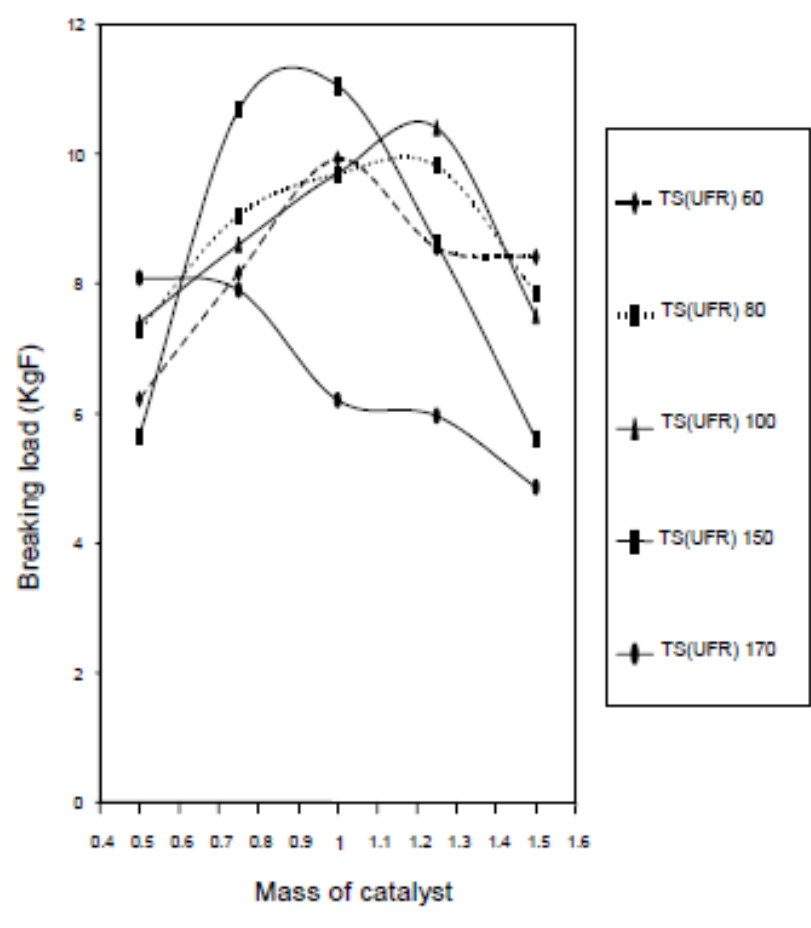

Fig. 28: Effect of temperature on breaking load of tetrasubstituted resinated cotton fabric at $\mathrm{pH}$ of 8 (WARP) 


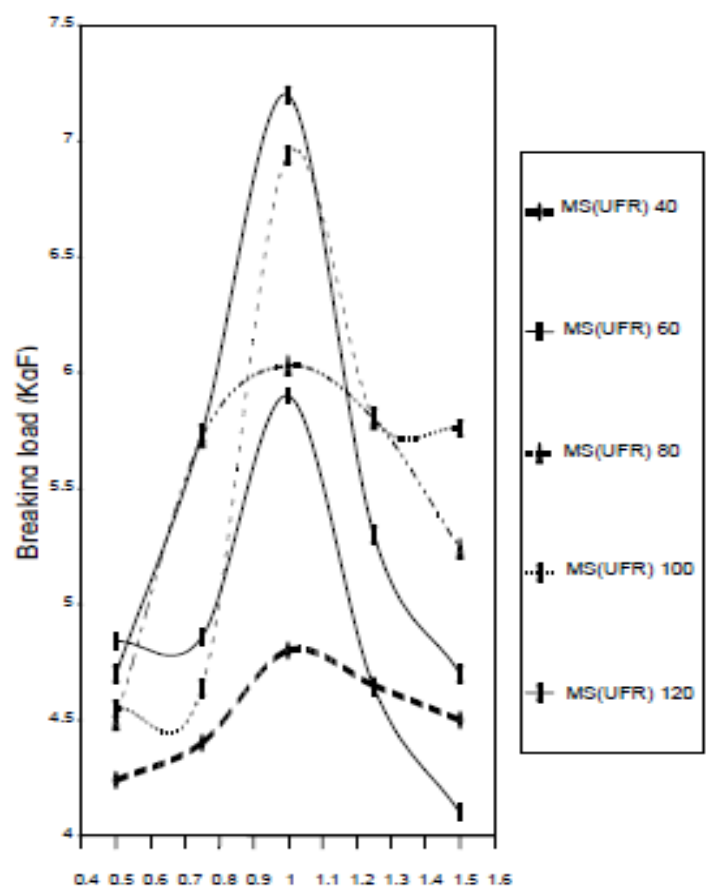

Mass of catalyst

Fig. 29: Effect of temperature on breaking load of mono substituted resinated cotton fabric at $\mathrm{pH}$ of 8 (WEFT)

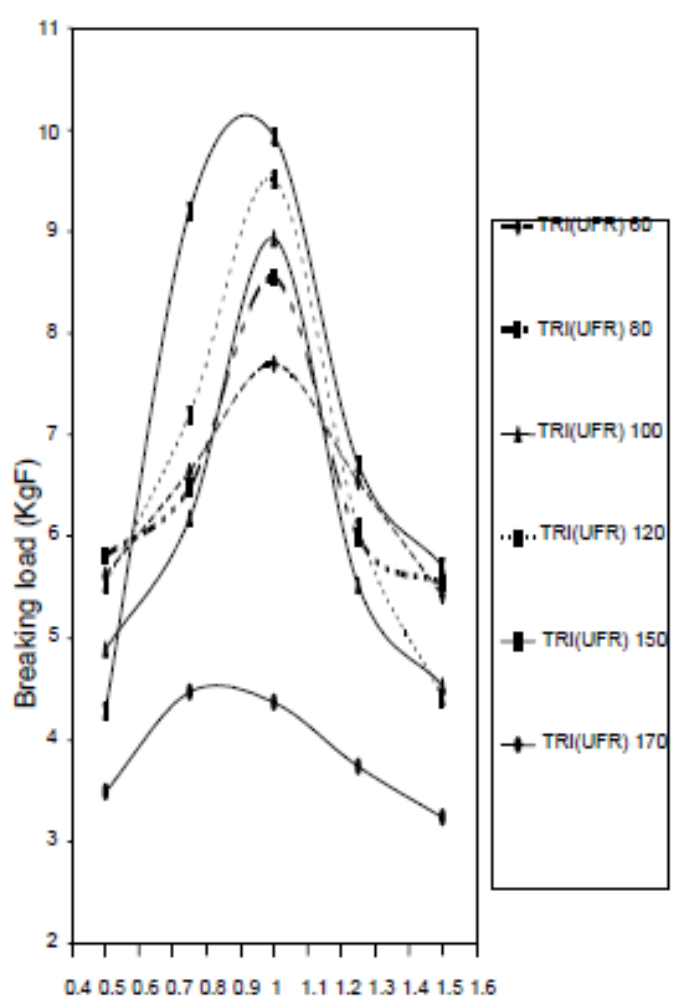

Mass of catalyst

Fig. 31: Effect of temperature on breaking load of trisubstituted resinated cotton fabric at $\mathrm{DH}$ of 8.0 (WEFT)

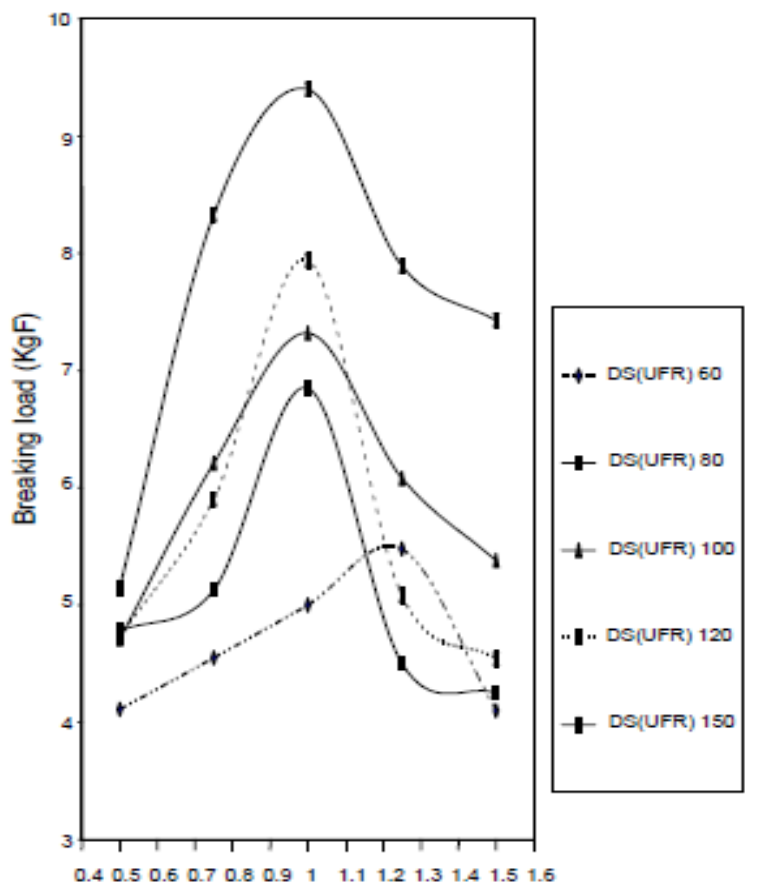

Mass of catalyst

Fig. 30: Effect of temperature on breaking load of disubstituted resinated cotton fabric at $\mathrm{pH}$ of 8 WEFT)

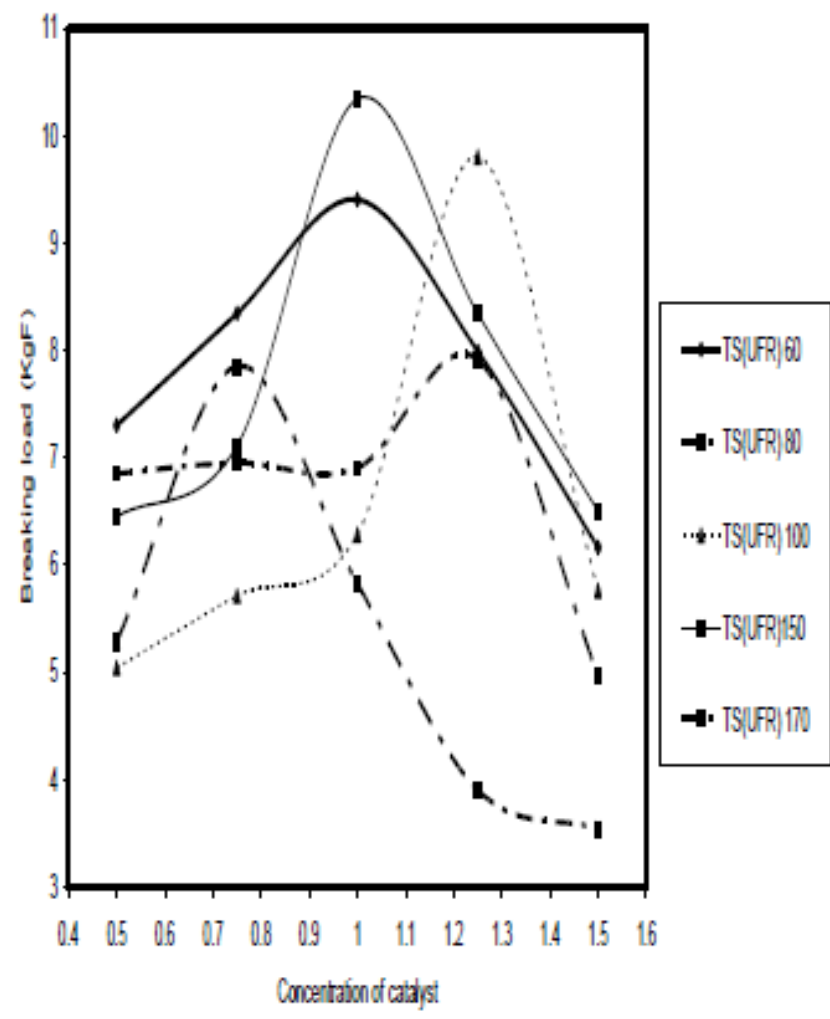

Fig. 32: Effect of temperature on breaking load of tetrasubstituted resinated cotton fabric at $\mathrm{pH}$ of 8 (WEFT) 


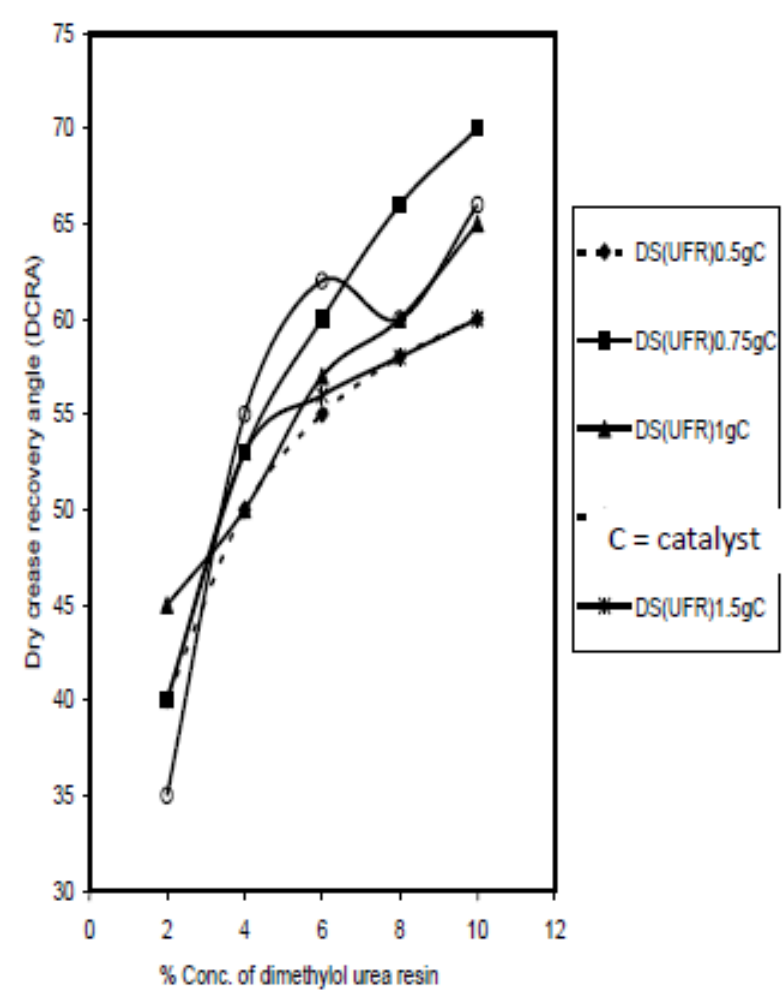

Fig. 14: Effect \% concentration of dimethylol urea resin on dry crease recovery angle (DCRA) of cotton fabric (WARP)

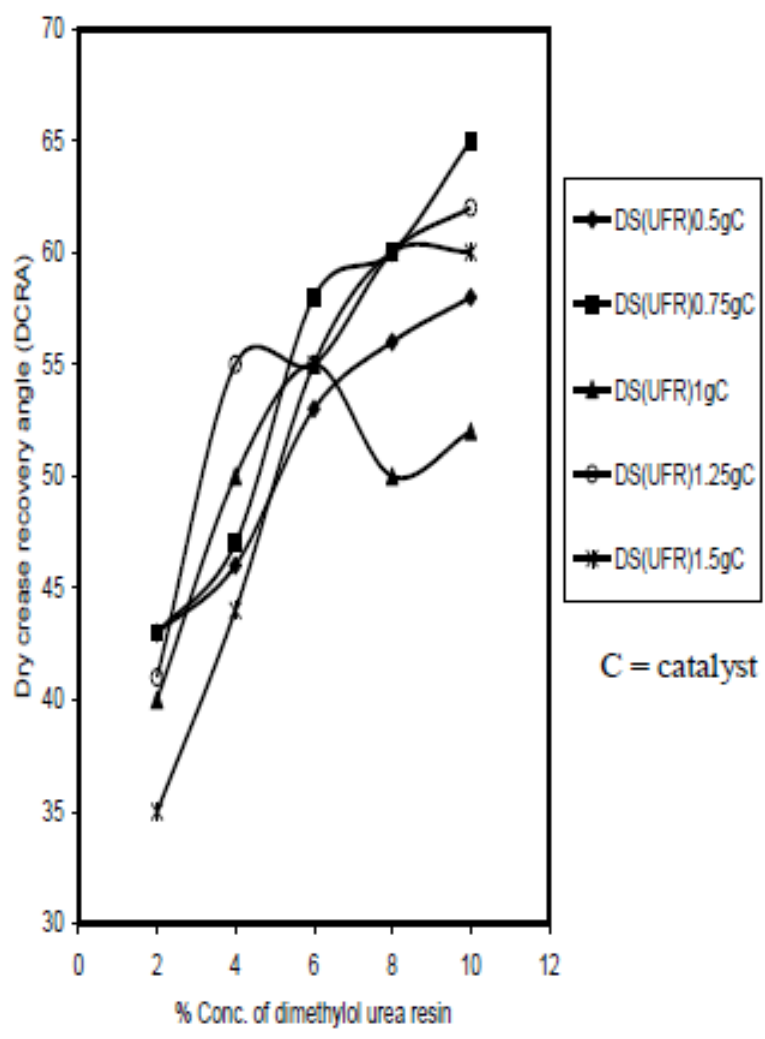

Fig. 17: Effect of \% concentration of dimethylol urea resin on dry recovery angle (DCRA) of mercerized cotton fabric (WEFT)

\section{DISCUSSION}

Effect of Temperature and Catalyst Mass on the Breaking Load of Methylol Urea Resinated Cotton Fabric at pH of 8.0

When a polymer enthalpy changes, a corresponding change in physical and chemical properties takes place. This is because the dipole forces which cause attraction between polar groups on different chains of the polymers are temperature dependent (Moji, 2000). The lower the temperature, the more effective the dipole forces, but becomes weaker at higher temperature. Curing is the process of raising temperature to chemically react the resin with the cellulose (Express Indiana, 2002). In garment finishing, resin curing is accomplished through the use of batch or continuous oven. Proper curing is required to achieve maximum abrasion and tear resistance during service (Express Indiana, 2002). Heat distribution should be even from top to bottom and side to side with a variation not more than $\pm 2^{\circ} \mathrm{C}$. Curing at $150^{\circ} \mathrm{C}$ to $155^{\circ} \mathrm{C}$ for 15 minutes gives desirable performance; curing time can be adjusted depending on the weight of the fabric. For heavy weight fabric the curing time can be increased or reduced for light weight fabrics. Allowing fabrics to over cure degrades the cotton due to excessive heat, distorting the attractive force between polar group of resin - cotton net work (Moji, 2000; Express Indiana, 2002). This degradation is particularly apparent when measuring the flex/abrasion, breaking load etc. As the temperature increases gradually to recommended curing temperature of $150^{\circ} \mathrm{C}$, it can be seen from Figs. 23-30 that the effect of temperature on the breaking load temperature curve is significant and controls the overall characteristic tensile strength (Moji, 2000; Express Indiana, 2002). Beyond $170^{\circ} \mathrm{C}$, the rigidity, yield strength and breaking load decreased while elongation increased (Cowie, 1991), this is evident in Figs 25-32 in both warp and weft directions.

Fig 25 shows the combine effects of catalyst mass and temperature on the breaking of mono substituted urea formaldehyde resinated cotton fabric sample (MSUFR 120). The sample gave a (BL) of $7.84 \mathrm{kgf}$ at $120^{\circ} \mathrm{C}$, this is closely followed by MSUFR 100 sample cured at $100^{\circ} \mathrm{C}$ with a BL of $7.40 \mathrm{kgf}$. Fig 26, revealed the effect of temperature and catalyst mass on the breaking load of disubstituted methylol urea resinated fabric (warp), DSUFRI50 giving a breaking load of $10.01 \mathrm{kgf}$ at $150^{\circ} \mathrm{C}$. This is followed by DSUFR 120 sample cured at $120^{\circ} \mathrm{C}$ and DSUFR60 at $60^{\circ} \mathrm{c}$ with a breaking load of $9.26 \mathrm{kgf}$ and $8.21 \mathrm{kgf}$ respectively. Further elevation in the mass of catalyst and temperature above fabric curing temperature of $155^{\circ} \mathrm{C}$ (DSUFR170) gave a breaking load of $9.26 \mathrm{kgf}$, this represents $8 \%$ reduction in tensile strength from the maximum breaking load of $10.01 \mathrm{kgf}$. 
Fig. 27: shows the fabric sample resinated with trisubstituted methylol urea (warp). This gave the maximum breaking load of $11.32 \mathrm{kgf}$ at $80^{\circ} \mathrm{C}$, followed by $10.6 \mathrm{kgf}$ at $150^{\circ} \mathrm{C}$ and $10.32 \mathrm{kgf}$ at $100^{\circ} \mathrm{C}$ within the range $0.75 \mathrm{~g}$ to $1.00 \mathrm{~g}$ of catalyst mass. Also further increase in catalyst mass and temperature up to $170^{\circ} \mathrm{C}$ gave a breaking load of $7.62 \mathrm{kgf}$, this represent $48 \%$ decrease in the tensile strength of the resinated fabric.

In fig. 28, Tetra substituted methylol urea resinated fabric (warp) cured at $150^{\circ} \mathrm{C}$ gave a B.L. of $11.05 \mathrm{kgf}$ and $10.40 \mathrm{kgf}$ at $100^{\circ} \mathrm{C}$. The trend repeated itself within catalyst mass range of $0.7 \mathrm{~g}$ to $1.0 \mathrm{~g}$ while elevation in temperature to $170^{\circ} \mathrm{C}$ was counter productive, and gave a breaking load of $8 \mathrm{kgf}$, representing a reduction of $38 \%$ in tensile strength when compared with the maximum $11.32 \mathrm{kgf}$.

Fig 29 and 30 captured the breaking load behavior of mono and disubstituted methylol urea resinated cotton fabric (weft) at various catalysts mass and temperature. The resination carried out at $120^{\circ} \mathrm{C}$ (MSUFR120) weft, gave the optimum breaking load of $7.20 \mathrm{kgf}$ at $1.0 \mathrm{~g}$ catalyst mass, MSUFR40 sample cured at $40^{\circ} \mathrm{C}$ gave the least breaking load, this further confirms the importance of temperature in fabric treatment.

Fig. 30 revealed the behavior of disubstituted methylol urea resinated cotton fabric (weft). Sample DSUFR150 gave the highest BL of $10.01 \mathrm{kgf}$, closely followed by sample DSUFR120, cured at $120^{\circ} \mathrm{C}$, which failed at $9.26 \mathrm{kgf}$. Subsequently, further elevation in curing temperature of samples up to $170^{\circ} \mathrm{C}$, gave breaking load of $9.26 \mathrm{kgf}$, representing $8 \%$ reduction in the tensile strength of sample. The trend replicated itself in fig. 31 and 32 which showed the effect of catalyst mass and temperature in the tetramethylol urea resinated cotton fabric in the weft direction. Sample TRIUFR $80^{\circ} \mathrm{C}$ and TSUFR 150 cured at $150^{\circ} \mathrm{C}$ gave a breaking load of $11.32 \mathrm{kgf}$ and $11.05 \mathrm{kgf}$ respectively between $0.5 \mathrm{~g}$ to $1.0 \mathrm{~g}$ catalyst mass. Subsequent elevation in temperature also reduce breaking load in both cases. Breaking load along the warp direction exceed that on the weft direction, reason being due to the amorphous regions of cellulose that are filled up with resins and strengthened by chemical cross-link between cellulose and resin molecules (Norma et al.; 1979). Cross-linking provides anchoring points for the chains in the network (Ajayi, 2001).

\section{Effects of Temperature and Catalyst Mass on Dry Crease Recovery Angle (DCRA) of Dimethylol Urea Resinated Cotton Fabrics(warp/weft)}

Fabrics used to produce garments should resist wrinkle during wearing, have a smooth appearance after washing and timble drying (Express Indiana, 2002). Creasing is chiefly due to the presence of weak Van Der Waal forces which characterized the amorphous regions; however when these regions are filled with low molecular weight resins, the crease recovery property is improved. Saunder (1973) and Ibrahim (1997) stated that when resins polymerize within the interstices of a material, the resistance of the material to creasing increases greatly. This is due to cross-link of resin and adjacent cellulose polymer chains, which gives cotton some elasticity, resiliency, and lower creasing propensity (Express Indiana, 2002). The recommended fibre wet pick up within 25 to 30 minutes of dipping and extraction is 65-70\% (Express Indiana, 2002). Crease recovery of fabrics measures therefore the ability of fabrics to resist wrinkle that would otherwise distort aesthetic appeal to modern customers. It also gives information on the flexibility or recoverability of material from wrinkle. A good fabric should after deformation recover rapidly from deformation.

Fig. 14 and17 show the result of DCRA of resinated cotton fabric at various mass of catalyst. The result revealed a gradual increase in the DCRA as the mass of catalyst, in the various substitutions increase. The $0.75 \mathrm{~g}$ of catalyst samples gave the highest crease recovery angle in weft and warp direction. There was no marked difference in their respective DCRA in the two directions. This result is consistent with that of Ajayi (2001), Boyede, (1994) and Eribo, (2001). It is observed that as degree of substitution increases, the DCRA also increases. This increase is not infinite, since there are finite glucose residue; a unit of cellulose molecule. Each unit of glucose residue contains three (3) free - OH groups (Moji, 2000), but since there are 100-200 glucose residue in cellulose molecule, there will be 300-600-OH groups in the cellulose. Thus when these site are filled, no further cross-linking reaction would take place; hence there would be a saturation point. This point marks the turning point or decrease in the DCRA observed in the above figures. Finally the DCRA of the warp direction is slightly higher than in the weft direction. This is due to higher amorphosity in the warp direction, filled up during resination, thus strengthening the weak hydrogen bonds, between the cellulose and methylol group, which enhanced the resilience and springiness of the material (Ajayi, 1997)

\section{CONCLUSION}

Acid damage of cotton-resin network was visible in all levels of the mechanical properties of the resinated samples tested. For optimum performance and profit maximization of methylol urea resins, should be prepared between $0.5 \mathrm{~g}$ to $1.0 \mathrm{~g}$ of catalyst. 


\section{REFERENCES}

[1] Ajayi, J.O., Bello, K.A. and Boyede, F.F. (2001). Effect of Liquid Ammonia Pre-treatment, on the Crease Recovery Properties of Resinated Cellulose Fabrics. Journal of Chemical Society, Nigeria 26(1):120-123.

[2] Ajayi, J.O. (2002). The Texi-Colour of a Dream Coat. Paper Presented at the $23^{\text {rd }}$ Series of University Inaugural Lecture of Abubakar Tafawa Balewa University, Bauchi.

[3] Ajayi, J.O. and Bello, K.A. (2005). Colour and Textile Chemistry. ${ }^{\text {st }}$ Ed., pp.5-11.

[4] American Society for Testing and Materials (1994). ASTM D 1424-83. Standard Test Method Tear Resistance of Woven Fabrics by Falling-

[5] Pendulum (Elemdrof) Apparatus, (7.01), Philadelphia, PA: ASTM.

[6] American Society for Testing and Materials (1995). ASTM D 5053-95 Standard Test Method Breaking Force and Elongation of Textile Fabrics (7.02). Philadelphia, PA: ASTM.

[7] Billimeyer, F.W. (1984). Textbook of Polymer Science. Wiley and Sons Inc., $3^{\text {rd }}$ Edition, John, New York, pp.441.

[8] British Standard Hankbook (1974).

[9] Cowie, J.M.G. (1973). Polymers: Chemistry and Physics of Modern Materials. International Textbook Company Limited, pp.342-368.

[10] Eschalier X BP 25, Vol.647, 1907; FP 34, Vol.24, 1906.

[11] Express Indiana (2002). Express Textile-Dyes and Chemical: What is Behind that Wrinkle Finish. www.apparel.indiamart.com., pp.1-8.

[12] Express Indiana (2002). Express Textile-Dyes and Chemicals: Everything you

[13] want to know about Wrinkle Resistant. www.apparel.indiamart.com, pp.1-13.

[14] Moji, A.B. (2000). Polymers: The Chemistry and Technology of Modern

[15] Materials. Yaba College of Technology, Yaba, Lagos, Concept Publications Ltd, pp.193-268.

[16] Norma, H., Jane, S. and Anna, L.L. (1979). Modern Textile. $5^{\text {th }}$ Ed., Macmillan Publishing Co. Inc, USA, pp.153-159.

[17] Peterson, H. (1987). The Chemistry of Crease-Resist Cross-linking Agents. Review of Progress in Coloration and Related Topics.

[18] Robert, W.P. (1975). Chemistry Experimental Foundations. University of Uttah, $2^{\text {nd }}$ Ed., Patience Hall, Inc., Englewood Cliff, New Jersey, pp.73, 124.

[19] Robert, J. and McGill (1980). Measurement and Control in Paper Making.

[20] Adam Hilger Ltd, Techno House, Redcliff Way, Bristol, BS1 6NX, Wolverhampton, Wr 100 JA, England, pp.311-312.

[21] Sadov, F., Korchagin, M. and Matetsky, A. (1967). "Chemical Technology of Fibrous Material". MIR Publishers, pp.14, 512, 642.

[22] Sanders, K.J. (1973). Organic Polymer Chemistry. Chapman and Hall, USA, pp.12-34, 300-317.

[23] Siriwan, K. and Marjorie, J.T.N. (2002). Polymerization-Crosslinking Fabric

[24] Finishing, with Pad-Dry-Cure, using Nonformaldehyde Catalyst Combinations to Impart Durable Press Properties. Department of Wear Environments, Virginia Polytechnic Institute and State University, Blacksburg, VA 24061, U.S.A.

[25] Trotman, E.R. (1975). Dyeing and Chemical Technology of Textile Fibres. Charles Griffin Co. Ltd, London, $4^{\text {th }}$ Ed., pp.318-325. 